\title{
Fungal Organisms Associated with Post-Harvest Fruits Collected from Markets of Tripura and Identified Through Use of Foldscope
}

\author{
Durga Prasad Awasthi*, Sumen Kapali, Dipika Debbarma and Swapna Tripura
}

Department of Plant Pathology, College of Agriculture, Lembucherra, Tripura West, Tripura -799 210, India

*Corresponding author

\section{A B S T R A C T}

\section{Keywords}

Zygomycetes, Deuteromycetes, Nematodes, Mites etc.

\section{Article Info}

Accepted:

22 March 2020

Available Online:

10 April 2020
Fungal biotic organisms associated with fruits has the ability to cause post-harvest loss both in terms of quantitative as well as qualitative manner resulting to directly or indirectly hampering the processing and value addition of fruits. Present case study was undertaken in the year 2018-19 and 2019-20 to identify fungal biotic organisms associated with commercially available fruits collected from the market of Tripura. Fruit samples were collected randomly from the different districts of the state throughout the year. Samples were examined in vivo as well as in vitro for presence of fungal organisms with the help of Foldscope (Origami microscope made up of cardstock, glass lens, light emitting diode and a diffuser panel etc.). Microscopic observation revealed that fungi under class Zygomycetes (Rhizopus sp. and Mucor sp.) and Deuteromycetes (Aspergillus sp., Penicillium., Alternaria., Fusarium sp.,) were mainly associated in post-harvest fruit rots of different fruits like Mango, Banana, Citrus sp. Apple, Pomegranate, Grapes, Rose Apple, Arecanut, Guava, Asian Palmyra Palm, Elephant Apple, Pear, Ber, Sapota etc. The vegetative as well as fruiting body of fungi including hyphae, sporangiophores, sporangiospores, conidia, conidiophores etc. were viewed and captured with the help of Foldscope. Besides, that nematodes and mites were also observed to be associated along with the fungi on these fruits.

\section{Introduction}

Postharvest losses refer to the losses that occur along the food supply chain due to pathogens infection, handling, storage, transportation and processing, thereby resulting in the reduction in quality, quantity and market value of agricultural commodities (Kader, 2005; Parfitt et al., 2010). Food and
Agriculture Organization reported that global average loss due to the food postharvest losses in North America, Europe and Oceania was about $29 \%$, compared to an average of about $38 \%$ in industrialized Asia, Africa, Latin America and South East Asia (FAO, 2011). Worldwide, postharvest losses have been estimated to be $50 \%$ of the harvested crop and much of this is due to rots caused by 
microorganisms (Coursey and Booth, 1972). It is estimated that about $20-25 \%$ of the harvested fruits and vegetables are decayed by pathogens during postharvest handling even in developed countries. In developing countries, postharvest losses are often more severe due to inadequate storage and transportation facilities (Sharma et al., 2009).

Post- harvest losses of fruits are a major concern for farmers, fruit sellers, traders in Tripura and other regions of world. Different fungal biotic organisms are responsible to cause significant yield loss of major fruits available under market condition of NorthEast India including Tripura.

Biotic fungal pathogens associated with fruits has the ability to cause post-harvest loss both in terms of quantitative as well as qualitative manner which directly or indirectly hampers processing and value addition of these fruits.

All these studies are carried out in different parts of India but little attention was given to know the present situation of post-harvest pathology under Agro-climatic condition of Tripura. Moreover, use of foldscope an origami-based microscope in identifying fungal biotic organisms associated with different fruits in vivo as well as in vitro conditions was also evaluated during present case of study.

Thus, the present case study was undertaken in the year 2018-19 and 2019-20 to identify fungal biotic organisms associated with commercially available fruits in the market conditions of Tripura.

\section{Materials and Methods}

Present study was undertaken in the year 2018-19 and 2019-20. Post-harvest fruits of major crops like Mango, Citrus spp., Banana, Pomegranate, Jackfruit, Apple, Grape, Rose
Apple etc including many other indigenous fruits and a nut was collected from different local markets of different districts of Tripura (Fig. 1). While collecting samples observations for association of microorganisms was undertaken by use of foldscope in vivo condition. A foldscope (Figure 2) is operated by inserting a sample mounted on a microscope slide turning on the LED, and viewing the sample while panning and focusing with one's thumbs. The sample is viewed by holding the foldscope with both hands and placing one's eye close enough to the micro-lens so one's eyebrow is touching the paper.

Panning is achieved by placing one's thumbs on opposite ends of the top stage and moving them in unison, thus translating both optics and illumination stages while keeping the stages aligned. Focusing is achieved using the same positioning of one's thumbs, except the thumbs are pulled apart (or pushed together). Unlike traditional microscopes, the foldscope anchors the sample at a fixed location while the optics and illumination stages are moved (Cybulski et al., 2014). In vitro conditions fruits were washed thoroughly followed by surface sterilization and incubation under favourable ambient temperature in B.O.D Incubator $\left(28+2^{0} \mathrm{C}\right)$. Samples were evaluated daily for development of mycelia outgrowth, rotting, decay etc. Tissue samples were then observed under foldscope - a paper microscope continuously for 14 days.

\section{Results and Discussion}

Results revealed that different classes of fungi belonging to Zygomycetes (viz.: Rhizopus sp., Mucor sp.,) and Deuteromycetes (Aspergillus sp.; Penicillium sp.; Colletotrichum gloeosporioides Penz.) are causing postharvest rots under market condition of Tripura. 
Table.1 List of Fungi observed in association with Postharvest Fruits through foldscope

\begin{tabular}{|c|c|c|}
\hline $\begin{array}{l}\text { Sl. } \\
\text { No. }\end{array}$ & $\begin{array}{l}\text { Name of Fruit or Sample } \\
\text { Observed }\end{array}$ & $\begin{array}{l}\text { Fungi observed in association with Postharvest Fruits } \\
\text { through Foldscope }\end{array}$ \\
\hline 1. & Mango (Mangifera indica) & $\begin{array}{l}\text { Colletotrichum gloeosporioides Penz } \\
\text { Hyphae, saucer shaped acervulus (Fig. 3) were viewed. } \\
\text { Mucor sp. } \\
\text { Sporanigophore, sporangium and sporangiospores were } \\
\text { viewed through foldscope (Fig 4). } \\
\text { Diplodia natalensis Pole Evans. } \\
\text { Hyphae, conidia etc were viewed through foldscope. }\end{array}$ \\
\hline 2. & Banana (Musa paradisiaca) & Colletotrichum gloeosporioides Penz. \\
\hline 3. & $\begin{array}{l}\text { Citrus spp. (Mandarin Orange, } \\
\text { Lemon, Lime, Sweet Orange) }\end{array}$ & $\begin{array}{l}\text { Mucor sp. } \\
\text { Rhizopus sp. } \\
\text { Apart from sporanigophore, sporangium and } \\
\text { sporangiospores, rhizoids and stolon were also viewed for } \\
\text { confirmation. } \\
\text { Aspergillus sp. } \\
\text { Hyphae, conidiophores and conidia were visible. } \\
\text { Penicilium italicum } \\
\text { Hyphae, conidiophores and conidia were visible. } \\
\text { Eryophite Mite }\end{array}$ \\
\hline 4. & $\begin{array}{l}\text { Asian Palmyra Palm } \\
\text { (Borassus flabellifer) }\end{array}$ & Unknown fungus (Identification not confirmed). \\
\hline 5. & Apple (Malus spp) & Mucor sp. \\
\hline 6. & $\begin{array}{l}\text { Pomegranate (Punica } \\
\text { granatum) }\end{array}$ & $\begin{array}{l}\text { Mucor sp. } \\
\text { Penicillium sp. }\end{array}$ \\
\hline 7. & Grapes (Vitis vinifera) & $\begin{array}{l}\text { Mucor } s p \text {. } \\
\text { Unknown fungus (Identification not confirmed). }\end{array}$ \\
\hline 8. & Rose Apple (Syzygium jambos) & Mucor sp. \\
\hline 9. & Arecanut (Areca catechu) & $\begin{array}{l}\text { Fusarium } s p \text {. } \\
\text { Crescent shaped macro-conidia, hyphae etc were visible } \\
\text { through Foldscope. } \\
\text { Nematode } \\
\text { Typical thread like structures of nematodes were visible } \\
\text { through foldscope. }\end{array}$ \\
\hline 10. & Guava (Psidium guajava) & $\begin{array}{l}\text { Unknown fungus (Identification not confirmed). } \\
\text { Eryophite Mite }\end{array}$ \\
\hline 11. & $\begin{array}{l}\text { Elephant Apple } \\
\text { (Dillenia indica) }\end{array}$ & Rhizopus sp. \\
\hline 12. & Jackfruit & Rhizopus sp. \\
\hline 13. & Ber (Ziziphus mauritiana) & Unknown fungus (Identification not confirmed). \\
\hline 14. & Sapota (Achras zapota) & Unknown fungus (Identification not confirmed). \\
\hline
\end{tabular}




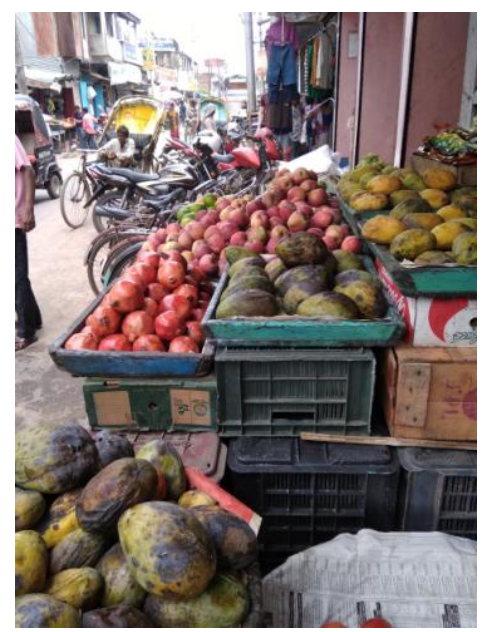

Fig.1 Postharvest rot on fruits observed at markets of Gomati District, Tripura, India

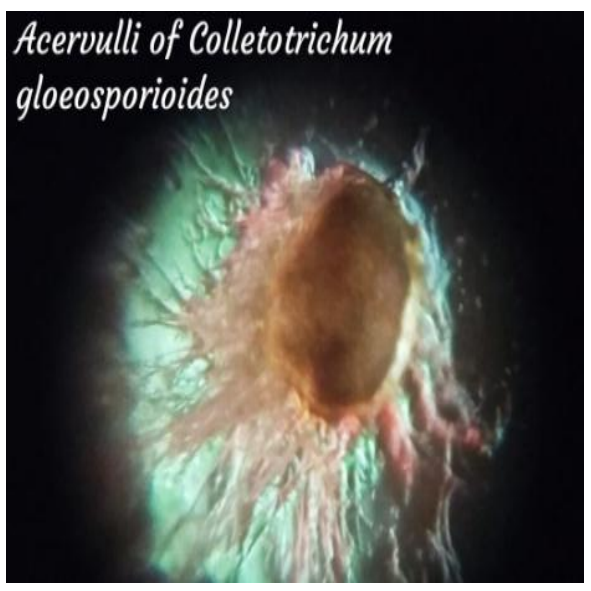

Fig.3 Acervulus of C. gloeosporioides Penz.

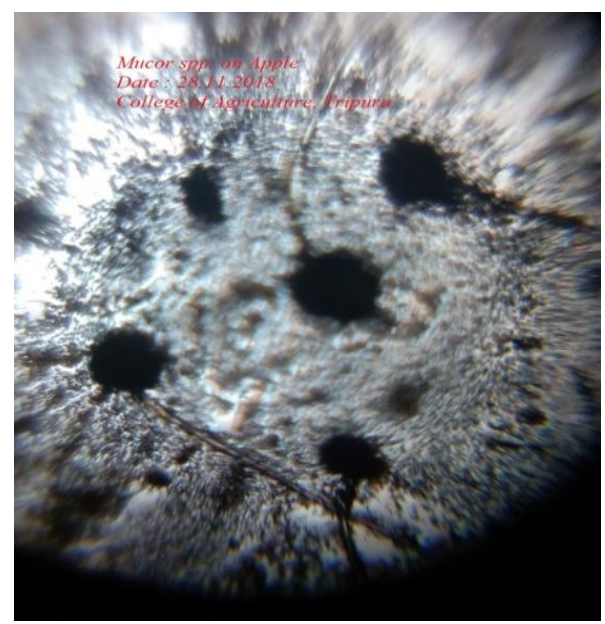

Fig.5 Mucor sp. from apple fruit.

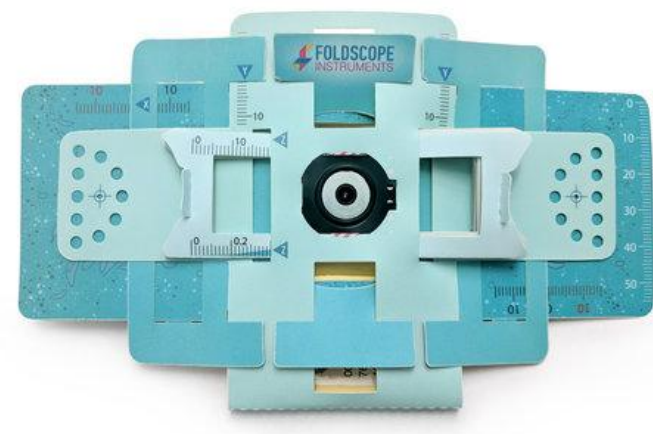

Fig.2 Foldscope

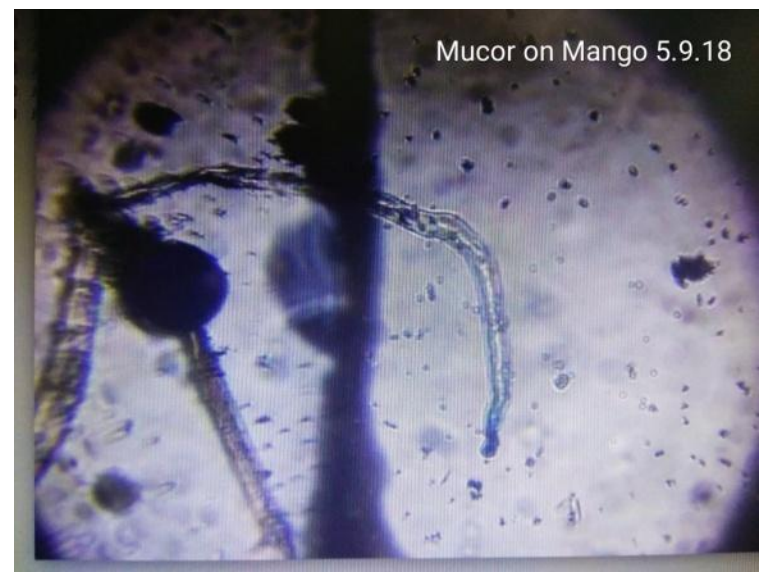

Fig.4 Sporangiophores, sporangium and spores of Mucor sp.

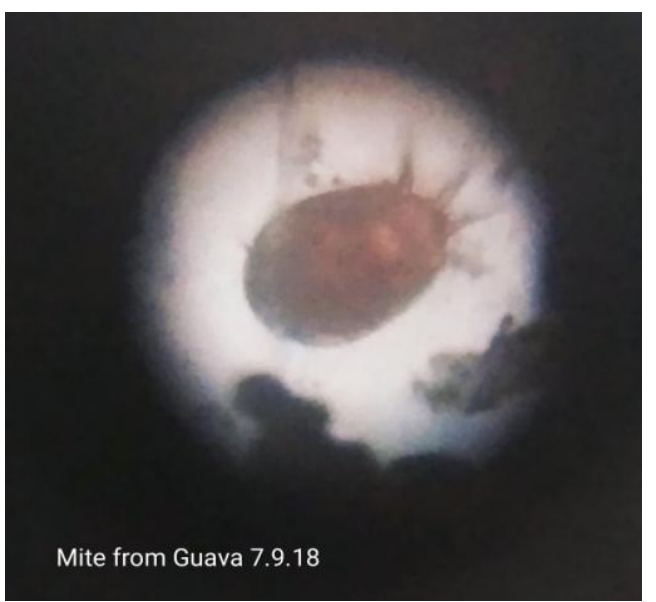

Fig.6 Mite from guava samples. 

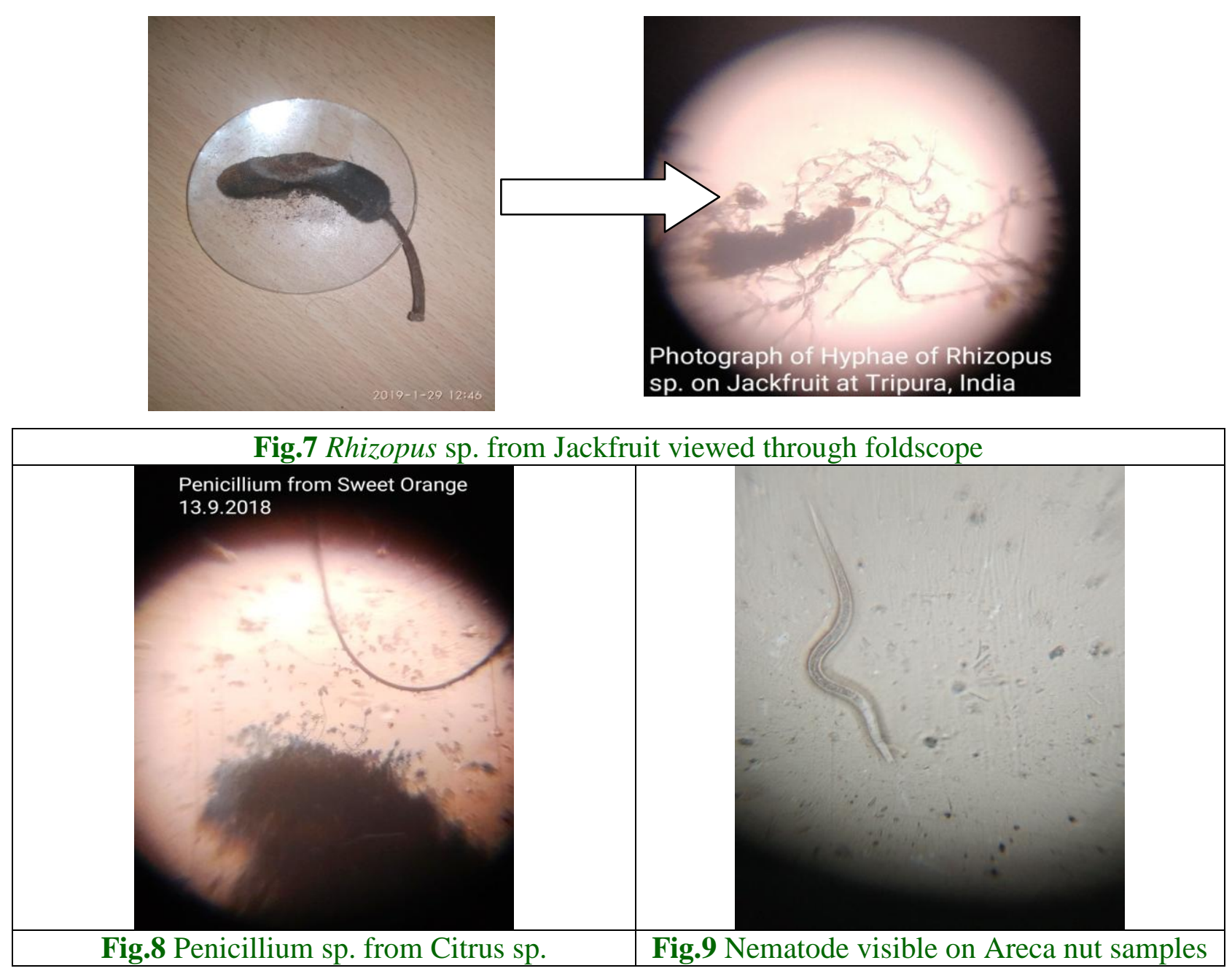

Colletotrichum gloeosporioides Penz was observed on Mango and Banana, Mucor spp. on Mango, Citrus spp., Apple, Pomegranate, Grapes and Rose Apple. Diplodia natalensis Pole Evans. on Mango, Rhizopus spp. was observed in Citrus, Jackfruit and Elephant Apple, Aspergillus spp. was observed in Citrus, Penicillium spp. in Citrus and Pomegranate, nematodes were observed in Arecanut while identification of many other fungi are not being confirmed.

The vegetative as well as fruiting body of fungi including hyphae, sporangiophores, sporangiospores, conidia, conidiophores etc. were viewed and well captured with the foldscope an origami-based paper microscope (Fig. 3 to Fig. 9). Whereas, bacteria were not being viewed by foldscope. But organisms like fungi, nematode and mites associated with fruit rotting are easily identifiable by use of (140 X magnification) foldscope during present course of study. Following microorganisms were observed with the help of foldscope (Table 1).

The result observed during present study is at par with work done by other workers in the past like Rinkey et al., 2014 reported fungal diseases of fruits and vegetables of about 19 fungal pathogens. Among these Alternaria solani, Aspergillus niger, Aspergillus fumigatus, Fusarium sp., Mucor sp., Penicillum sp. and Rhizopus sp., were found to be major disease-causing organisms. They revealed that fungal infection is mainly due to 
injury during storage and handling. Species of Fusarium, Alternaria and Aspergillus were found to be the disease-causing organisms responsible for extensive damage to fruits and vegetables in the markets of Nagpur region of India. The fungi like Aspergillus, Fusarium, Rhizopus, Mucor and Penicillium species were found on edible fruits which may also causes allergenic effects on human health.

Aspergillus, Penicillium, Rhizopus and Mucor are found very dominant pathogens on fruits and vegetables. Singh et al., 2017 also reported that a wide variety of fungal and bacterial pathogens causes postharvest disease in fruits. Some of these infect produce before harvest and then remain quiescent until conditions are more favourable for disease development after harvest.

During the present case of study some fungi are not being identified. Future course of action should be aimed to identify all these associated fungi in taxonomical level as well as molecular level and to sort out management strategies against these associated fungi causing significant postharvest loss.

\section{Acknowledgment}

It is to acknowledge herewith grant received from Department of Biotechnology, Ministry of Science \& Technology, Govt. of India under Foldscope Project.

\section{References}

Coursey, D. G. and Booth, R. H. 1972. The post-harvest phytopathology of perishable tropical produce. Rev. Plant Pathol. 51:751-65.

Cybulski, J.S., Clements, J. and Prakash, M. 2014. Foldscope: Origami-Based Paper Microscope, (6), 9. https://doi.org/10.1371/journal.pone.009 8781.

Food and Agriculture Organization of the United Nations., 2011. Global Food Losses and Food Waste: Extent, Causes and Prevention; FAO: Rome, Italy.

Kader, A.A. 2005. Increasing food availability by reducing postharvest losses of fresh produce. Int. Postharvest Symp. Acta Hort. 682: 2169-2178.

Parfitt, J., Barthel, M. and Macnaughton, S. 2010. Food waste within food supply chains: Quantification and potential for change to 2050. Philos. Trans. R. Soc. 365: 3065-3081.

Rinkey P., Thakur U. and Dongarwar N., 2014. Post-harvest fungal diseases of fruits and vegetables in Nagpur. Int. J. of Life Sciences. Special issue, A2: 56-58.

Sharma, R.R., Singh, D. and Singh, R. 2009. Biological control of postharvest diseases of fruits and vegetables by microbial antagonists: A review. Biological Control, 50: 205-221.

Singh, B.K., Yadav, K.S., and Verma, A. 2017. Impact of Post-harvest diseases and their management in fruit crops: An overview. J. Bio. Innov. 6 (5): 749-760.

\section{How to cite this article:}

Durga Prasad Awasthi, Sumen Kapali, Dipika Debbarma and Swapna Tripura. 2020. Fungal Organisms Associated with Post-Harvest Fruits Collected from Markets of Tripura and Identified Through Use of Foldscope. Int.J.Curr.Microbiol.App.Sci. 9(04): 2543-2548. doi: https://doi.org/10.20546/ijcmas.2020.904.305 